\title{
An Exploratory Factorial Analysis of Teachers' Perceptions of Perceived Pedagogical Benefits of Adoption of Information and Communication Technology in Teaching and Learning
}

\author{
D.W. Govender (PhD) \\ Discipline of Computer Science Education, University of KwaZulu-Natal \\ Private Bag X03, Ashley, 3605, South Africa \\ Email: govenderd50@ukzn.ac.za \\ M. Dhurup (PhD) \\ Faculty of Management Sciences, Vaal University of Technology \\ Private Bag X021, Vanderbijlpark, 1900, South Africa \\ Email: royd@vut.ac.za
}

\section{Doi:10.5901/mjss.2014.v5n20p1214}

\section{Abstract}

In the current information society, the need for teachers to be adequately equipped with information and communication technology (ICT) competency has become essential for teaching in a classroom. This paper investigates factors affecting the perceived pedagogical benefits of adoption of ICT by teachers. The study also sought to establish any variations in terms of age and the established benefits of ICT adoption. The sample comprised 1222 teachers employed in public secondary schools in the greater Durban area in the province of KwaZulu-Natal in South Africa. Descriptive analysis, factor analysis and correlations were used to analyse the data. Through an exploratory procedure six factors - ICT confidence, learning enhancement, work enhancement, work enjoyment, positive attitude towards learning tool, and teaching enhancement emerged that describe the perceived pedagogical benefits of the use of ICT. It is our recommendation that placing technology at the disposal of educators is not sufficient to ensure use - measures must be in place that will ensure teacher confidence and a positive attitude. Effective implementation of ICT in schools is a multifaceted, complex process that does not just involve providing the technology to schools, but also involves teachers' competencies, schools' readiness, long-term financing, curriculum restructuring, and the Government's willingness to invest in the teaching and learning infrastructure.

Keywords: Teachers, information and communication technology, technology adoption, learning enhancement, work enhancement

\section{Introduction}

Access and the digital divide have always been an issue for education in many countries, and numerous studies have focused on technology as a means of enhancing learning (Cutrim, 2008; Carle, Jaffee, \& Miller, 2009). Moreover, many studies have focused on technology integration, concluding that using technology in educational settings benefits students ( Gülbahar, 2007; Kim \& Hannifin, 2011; Govender \& Govender, 2013). Neyland (2011) and Yilmaz (2011) raised the issue of infrastructure and access to technology as factors affecting integration of information and communication technology (ICT) adoption among teachers. Within classroom settings forces at the micro-and macrolevel of the educational systems (educators and learners) may be influential in facilitating or impeding adoption of ICT integration in classrooms (Pelgrum, 2001). Researchers reiterate that technology adoption or diffusion in any context depends on shared negotiation of values and priorities, particularly on how the technology fits into the existing social purposes and practices of the community (Wilson, Sherry, Dobrovolny, Batty \& Ryder, 2002; Celik \& Yesilyurt, 2013; Kutluca \& Ekici, 2010).

Studies have shown that successful implementation of educational technologies depends largely on the attitudes of teachers (Kersaint, Horton, Stohl \& Garofalo, 2003; Govender, 2006). For example, Bullock (2004) and Govender (2012) posit that educators' attitudes are a major enabling/disabling factor in the adoption of technology. Development of a positive user attitude towards ICT adoption is essential not only for enhancing computer integration, but also for avoiding educators' resistance to computer use in classrooms. Kutluca and Ekici (2010) add that in order to bring an innovation to scale, an important first step is to understand how the innovations are adopted in local contexts. It is hence 
recommended that if any online pedagogical approach is going to be used by students in school, there must be a good fit with the teachers' intentions, perceptions and actions with regard to the classroom culture (Kutluca \& Ekici, 2010).

Teachers generally hold their own set of beliefs that determine the precedence for pedagogical knowledge and how students acquire knowledge (Liu, 2011). A commonly used distinction in studies is associated with two pedagogical paradigms, often referred to as teacher-centred or teaching-oriented belief, and learner-centred or learning-oriented belief (Schuh, 2004; Meirink, Meijer, Verloop, \& Bergen, 2009).

The teacher-centred belief is based on an assumption of knowledge delivery that resembles traditional teaching methods, and underscores the importance of knowledge reproduction, while the learner-centred belief emphasises student responsibility for learning and is focused on knowledge construction and how students are induced to work and learn together. In terms of acquiring knowledge, teacher beliefs about teaching and learning can be broadly classified into the knowledge transmission or knowledge construction category (Chan \& Elliot, 2004; Samuelowicz \& Bain, 2001). Thus, teacher beliefs typically encompass teacher-centred and learner-centred pedagogical beliefs (Chai, Hong \& Teo, 2009).

It has also been argued that constructivist pedagogical beliefs of teachers about teaching and learning are significant in determining patterns of technology usage in classrooms (Higgins \& Moseley, 2001; Inan \& Lowther, 2010). Honey and Moeller (1990) demonstrated that teachers who held constructivist pedagogical beliefs successfully integrated technology into instruction. Ertmer (2005) indicated that teachers who have strong constructivist pedagogical beliefs or approaches have a greater propensity to use technology in the classroom than teachers who have traditional pedagogical beliefs, who consider themselves mere transmitters of knowledge to learners.

While South Africa still lags behind in ICT development, the Government has made some attempts to address this (Department of Education (DoE, 2003). The Government has responded in trying to bridge the digital divide by introducing a range of measures, which included the Presidential National Commission on Information Society and Development. The Commission comprised members of both the public and private sector, and its main goal was to act as an advisory group to Government on challenges regarding ICT development in South Africa and how the country could address these in order to be globally competitive. The Electronic and Communications Transaction Act, No. 25 of 2002, was established by the Department of Communications in a bid to lead all ICT initiatives in South Africa and to develop a five-year national e-strategy which would empower all citizens, especially the education sector.

Explaining user acceptance and adoption of a new technology is often described as one of the most mature research areas in the contemporary ICT systems literature (Hu, Chau, Sheng \& Tam, 1999). Over the years researchers in this area have developed several theoretical models, with roots in information systems, psychology and sociology that routinely explain over $40 \%$ of the variance in individual intention to use technology (Govender, 2006; Davis, Bagozzi \& Warshaw, 1989; Taylor \& Todd 1995; Venkatesh \& Davis, 2000). A brief overview is provided of some of the widely used models in ICT systems literature.

\subsection{Underlying Theories in User Acceptance of ICT}

Ajzen and Fishbein's (1980) 'Theory of reasoned action' (TRA) was developed in 1967. The main premise of this theory is that a person's intention is the main predictor and influencer of behaviour. If a person intends to do something, then they will more than likely do it. The TRA suggests that there are two main influencers of intention: the attitude toward the behaviour, and subjective norms. TRA posits that individual behaviour is driven by behavioural intentions, where these are a function of an individual's attitude toward the behaviour, and subjective norms surrounding performance of the behaviour. The second area, attitude toward the behaviour, is defined as the individual's positive or negative feelings about performing a particular behaviour; this is determined through assessment of one's beliefs regarding the consequences arising from a particular behaviour, and evaluation of the desirability of these consequences.

The Theory of planned behaviour (TPB) is actually an extension of TRA which posits that individual behaviour is driven by behavioural intentions where these are a function of an individual's attitude toward the behaviour, the subjective norms surrounding the performance of the behaviour, and the individual's perception of the ease with which the behaviour can be performed (behavioural control). Behavioural control is an added dimension in TPB, and is defined as one's perception of the difficulty of performing a particular behaviour. TPB views the control that people have over their behaviour as lying on a continuum from behaviours that are easily performed to those requiring considerable effort and resources.

The Technology acceptance model (TAM) is an information systems theory that models how users come to accept and use a technology. TAM suggests that when users are presented with a new software package or innovation, a number of factors influence their decision about how and when they will use it, notably: perceived usefulness, defined by Davis (1989) as "the degree to which a person believes that using a particular system would enhance his or her job 
performance"; and perceived ease of use, defined by Davis (1989) as "the degree to which a person believes that using a particular system would be free from effort".

TAM replaces many of TRA's attitude measures with the two technology acceptance measures 'ease of use' and 'usefulness'. TRA and TAM, both of which have strong behavioural elements, assume that when someone forms an intention to act, they will be free to act without limitations. In the real world, however, there will be many constraints, such as limited ability, time constraints, environmental or organisational limits, or unconscious habits which limit the freedom to act (Govender \& Maistry, 2012; Bagozzi, Davis \& Warshaw, 1992).

In an attempt to integrate the main competing user acceptance models, Venkatesh, Morris, Davis and Davis (2003) formulated the Unified theory of acceptance and use of technology (UTAUT). This model was found to outperform each of the individual models (Venkatesh, Morris, Davis \& Davis, 2003). The theory holds that four key constructs (performance expectancy, effort expectancy, social influence, and facilitating conditions) are direct determinants of usage intention and behaviour (Venkatesh et al., 2003). Gender, age, experience, and voluntariness of use are posited to mediate the impact of the four key constructs on usage intention and behaviour (Venkatesh et al., 2003).

The theory was developed through review and consolidation of the constructs of eight models that earlier research had employed to explain information systems usage behaviour (TRA, TAM, and motivational model, TPB, a combined theory of planned behaviour/technology acceptance model, model of $P C$ utilisation, innovation diffusion theory, and social cognitive theory). Subsequent validation of UTAUT in a longitudinal study found it to account for $70 \%$ of the variance in usage intention (Venkatesh et al., 2003).

A number of researchers (Govender \& Govender, 2009; Voogt, 2010; Ward \& Parr, 2010; Friedman \& Friedman, 2011) view computers as having an influential effect on teaching and learning processes. They posit that with the use of computers in the classroom, schools would become more learner-centred, and that more individualised learning would take place than ever before. In learner-centred classrooms, with the aid of computers, learners are able to collaborate, to use critical thinking and find alternative solutions to problems (Jaber, 1997; Govender, 2010).

However, the shift from educator-centred delivery to a learner-centred model potentially leads to resistance to change. Learner-centred teaching has challenged teachers to review their teaching and learner learning methods and the outcomes (Jaber, 1997). Research undertaken by Dwyer, Ringstaff and Sandholtz (1991) suggests that computers can be used in collaboration for all subject areas, but that educators have to take into account the different styles of teaching and the learners involved in a learning environment. This type of teaching requires a change in both the educator's method of teaching and the methods of learning, the amount of time needed to learn how to use the technology, and the location of models that work in synergy with technology (Ko0, 2008).

Hence, the purpose of this study was to ascertain the factors that influence teachers' perceptions of perceived benefits of the adoption of ICT in teaching and learning.

\section{Methodology}

This research used a survey approach to investigate various aspects of teachers' perceptions towards the adoption of ICT in the classroom. The survey questionnaire was created with items validated in previous research (Davis, 1989; Davis et al., 1989; Venkatesh \& Davis, 2000; Vannatta \& O'Bannan, 2002; Abdulkifi Albirini, 2006 Venkatesh et al., 2003) and adapted for this study. Development of the questionnaire was guided by an extensive review of the literature.

The questionnaire consisted of 17 elements, comprising demographic and perceptual data. The instrument was also evaluated by the DoE's Research, Strategy and Policy Development Unit and the University of KwaZulu-Natal's ethical clearance committee. Feedback was mainly used to ensure that the scales measure the content areas under investigation, and are culturally and technically appropriate for the context of the study.

Correlations and factor analysis was used in analysis of the data. According to Tabachnick and Fidell (2001) it is quite common to use principal component analysis as a preliminary extraction technique, followed by other technique(s) with varying numbers of factors, communality estimates, and rotational methods with each run. Analysis ends when the researcher decides on the preferred solutions (Tabachnick \& Fidel, 2001, p. 611). Hence, the exploratory factor analysis with principal component extraction and varimax rotation method was first conducted.

\subsection{Sample and Data Collection}

The sample comprised teachers in public secondary schools located in the greater Durban region in the province of KwaZulu-Natal in South Africa. Questionnaires were distributed to 191 schools. Some schools received their questionnaires via the circuit office and others received them via post. Most Circuit Managers were cooperative in 
assisting in the distribution and collection of these questionnaires. However, there were a few who emphatically did not want to assist with this study, and this made collection of questionnaires from these schools very difficult.

We received returns from 93 schools, a 55.4\% rate of return. In total we received 1237 questionnaires back from schools. There were 15 questionnaires that we considered to be spoilt because they were partially completed, illegible, or had contradictory entries. Data from 1222 questionnaires have been used. This sample size adequately satisfies Leedy and Ormrod's (2005) requirements (as stated below), since the total number of secondary educators in the region stood at 8026 as per the DoE's Education Management and Information Systems (EMIS) database. The 1222 responses that we used represent a total of $15.23 \%$ of our sampling frame.

Gay and Airasian (as cited in Leedy \& Ormrod, 2005:25) offer the following guidelines for selecting a sample size:

$>$ For small populations (fewer than 100 people) there is little point sampling, therefore one should survey the entire population.

$>$ If the population size is around 500 , one should sample at least $50 \%$ of the population.

$>$ If the population size is around 1500 , then one should sample at least $20 \%$ of the population.

$>$ Beyond a certain point (about 5000 or more), one should sample at least 400 of the population.

The sample is fairly representative because every alternate school in a district was chosen and this represents $50 \%$ of the secondary schools in the Ethekweni region. Secondary schools were chosen because the Draft White Paper on e-Education (DoE, 2003:22) has made access to ICT infrastructure a priority in secondary schools: "Every educator and learner in General and Further Education and Training (FET) must have access to ICT infrastructure".

\subsection{Instrumentation}

The survey questionnaire was adapted from Vannatta and O'Bannon (2002) and Albirini (2006. The first section of the questionnaire solicited information on gender, ethnicity, age, subjects taught in schools, educational qualifications and general use of computers and the Internet. The second part of the questionnaire comprised questions relating to teachers' perceived readiness and attitudes towards adoption of information technology anchored on five-point Likert scales ranging from $1=$ strongly disagree to $5=$ strongly agree.

\subsection{Ethical Considerations}

Ethical clearance was sought from the DoE in KwaZulu-Natal to conduct the research, and permission was granted by the school principals to conduct the research. To ensure their safety and rights, the participants were informed about the prevailing ethical considerations, for instance, informed consent, voluntary participation (and rights of the participants to withdraw from the survey), anonymity and confidentiality. Informed consent was obtained from each participant. Further, the researchers ensured that the participants received full disclosure of the nature of the study, benefits and alternatives, with an extended opportunity to ask questions.

\section{Results and Discussion}

The results are reported in the following sequence: first the composition of the sample and general profile of teachers; thereafter, correlation analysis and exploratory factor analysis to establish underlying factors relating to perceived benefits of adoption of ICT in teaching and learning.

\subsection{Sample Composition}

The target population in this study is secondary school educators in the greater Durban area of KwaZulu-Natal. The list of educators is based on the DoE's EMIS list, which is maintained and updated on an annual basis by the Provincial DoE. The total number of secondary schools in the region on the DoE's EMIS list was 403. Of these schools, 382 have staff ranging from 2 to 60, and the balance of 21 schools show 0 staff members. We chose, at random, every alternate school and had a sample of 191 schools. The region is made up of three districts, viz. llembe, Pinetown and Umlazi. Once the sample had been chosen, the number of schools per district was as shown in Table 1. 
Table 1: Distribution of Schools

\begin{tabular}{|l|c|}
\hline District & Number of schools \\
\hline llembe & 57 \\
\hline Pinetown & 68 \\
\hline Umlazi & 66 \\
\hline Total & 191 \\
\hline
\end{tabular}

\subsection{Reliability and Validity}

Reliability coefficients for each perceived benefit's sub-scales are reported in Table 2, together with descriptive statistics for each scale and example items. Reliability of the instruments was examined using Cronbach's alpha. According to Nunnally and Bernstein (1994), a value of 0.70 is sufficient for early stages of research in order to establish internal consistency. The six sub-scales met this requirement, as the reliability values ranged from 0.701 to 0.798 .

Construct validity was established through factor analysis. The instrument met the requirements of construct as each variable loaded on one factor only, with no evidence of cross-loading. Convergent validity was established through the computation of correlation analysis. These results are reported in Table 2. The six perceived sub-scales showed moderate to strong correlations among the latent constructs, with $r$ values ranging from 0.252 to 0.555 , which was significant at a level of $P<0.01$, thus providing evidence of convergence among the latent constructs.

Table 2: Correlations - Latent Constructs Relating to Perceived Benefits in ICT Adoption

\begin{tabular}{|l|c|c|c|c|c|c|}
\hline Factors & F1 & F2 & F3 & F4 & F5 & F6 \\
\hline ICT competence (F1) & 1.000 & $0.427^{* *}$ & $0.333^{* *}$ & $0.404^{* *}$ & $0.342^{* *}$ & $0.312^{* *}$ \\
\hline Learning enhancement (F2) & $0.427^{* *}$ & 1.000 & $0.502^{* *}$ & $0.517^{* *}$ & $0.444^{* *}$ & $0.406^{* *}$ \\
\hline Work enhancement (F3) & $0.333^{* *}$ & $0.502^{* *}$ & 1.000 & $0.555^{* *}$ & $0.359^{* *}$ & $0.434^{* *}$ \\
\hline Enjoyment (F4) & $0.404^{* *}$ & $0.517^{* *}$ & $0.555^{* *}$ & 1.000 & $0.407^{* *}$ & $0.456^{* *}$ \\
\hline Learning tool (F5) & $0.342^{* *}$ & $0.444^{* *}$ & $0.359^{* *}$ & $0.407^{* *}$ & 1.000 & $0.252^{* *}$ \\
\hline Teaching enhancement (F6) & $0.312^{* *}$ & $0.406^{* *}$ & $0.434^{* *}$ & $0.456^{* *}$ & $0.252^{* *}$ & 1.000 \\
\hline${ }^{* *}$ Correlation is significant at the 0.01 level (two-tailed). & & & \\
\hline
\end{tabular}

\subsection{Factor Structure}

Factor analysis with the principal components method and varimax rotation was used to summarise the variables into underlying sets of factors. Through factors analysis variables can be reduced into factors, each reflecting an underlying property which is commonly shared by a group of variables (De Vaus, 2002). In order to determine the number of factors to be extracted, several rotation solutions were compared, taking into account the percentage of explained variance, the scree plot and the eigenvalue criterion. Finally, a six-factor solution was developed as the items were logically associated with the underlying factors. The six factors accounted for approximately $60 \%$ of the variance, with eigenvalues ranging from 6.37 to 1.05. The final factor structure is shown in Table 3.

Table 3: Factor Loading Matrix, Descriptive and Psychometric Scale Properties

\begin{tabular}{|l|c|c|c|c|c|c|c|c|c|}
\hline \multirow{2}{*}{ Variable description } & \multicolumn{4}{|c|}{ Components } & \multicolumn{2}{c|}{ Descriptive and psychometric scale properties } \\
\cline { 2 - 10 } & F1 & F2 & F3 & F4 & F5 & F6 & Means & Item-total correlation & Cronbach's alpha \\
\hline C12 Easy to learn & 0.144 & 0.060 & 0.272 & 0.194 & $\mathbf{0 . 5 5 4}$ & 0.013 & 3.90 & 0.420 & \multirow{2}{*}{0.706} \\
\hline C14 Effective learning tool & 0.134 & 0.134 & 0.320 & 0.033 & $\mathbf{0 . 6 2 7}$ & 0.227 & 4.24 & 0.541 & \\
\hline C15 Educational tool & 0.037 & 0.130 & 0.027 & 0.066 & $\mathbf{0 . 7 9 5}$ & 0.024 & 4.10 & 0.521 & \multirow{2}{*}{0.709} \\
\hline C16 Use for educational purposes & 0.021 & 0.010 & 0.054 & 0.010 & $\mathbf{0 . 7 5 0}$ & 0.205 & 3.75 & 0.495 & \\
\hline C2 More advantages & 0.091 & 0.186 & 0.210 & 0.115 & 0.041 & $\mathbf{0 . 6 7 2}$ & 4.09 & 0.486 & \multirow{2}{*}{0.798} \\
\hline C4 Subject more interesting & 0.243 & 0.223 & 0.152 & 0.110 & 0.157 & $\mathbf{0 . 7 0 4}$ & 4.26 & 0.599 & \\
\hline C6 Fits with curriculum & 0.251 & 0.064 & 0.117 & 0.167 & 0.216 & $\mathbf{0 . 6 6 9}$ & 3.98 & 0.524 & \\
\hline B17 Save time & 0.691 & 0.141 & .147 & 0.071 & 0.008 & 0.261 & 3.40 & 0.569 & \\
\hline B18 Use computers often & 0.779 & 0.207 & 0.025 & 0.160 & 0.108 & 0.114 & 4.21 & 0.681 & \\
\hline B19 Learn more with computers & 0.766 & 0.166 & 0.134 & 0.061 & 0.035 & 0.162 & 4.45 & 0.636 & \\
\hline
\end{tabular}




\begin{tabular}{|c|c|c|c|c|c|c|c|c|c|}
\hline B20 Use in the future & 0.688 & 0.320 & 0.008 & 0.175 & 0.105 & 0.013 & 4.52 & 0.577 & \\
\hline B10 Good to learn & 0.125 & 0.591 & 0.006 & 0.187 & 0.041 & 0.005 & 4.54 & 0.385 & \multirow{5}{*}{0.720} \\
\hline B12 Good information search & 0.054 & 0.583 & 0.151 & 0.024 & 0.033 & 0.266 & 4.67 & 0.420 & \\
\hline B13 Like use in the classroom & 0.195 & 0.661 & 0.091 & 0.205 & 0.044 & 0.087 & 4.54 & 0.541 & \\
\hline \begin{tabular}{|l|} 
B14 Enhance learning \\
\end{tabular} & 0.262 & 0.650 & 0.155 & 0.011 & 0.080 & 0.157 & 4.39 & 0.521 & \\
\hline B15 Do more good than harm & 0.180 & 0.655 & 0.097 & 0.125 & 0.152 & 0.062 & 4.27 & 0.495 & \\
\hline D4 Earns respect & 0.067 & 0.040 & 0.636 & 0.023 & 0.035 & 0.183 & 4.27 & 0.435 & \multirow{5}{*}{0.707} \\
\hline D6 Improve work & 0.108 & 0.056 & 0.699 & 0.121 & 0.099 & 0.301 & 3.57 & 0.585 & \\
\hline D7 Learn about traditions & 0.022 & 0.112 & 0.595 & 0.144 & 0.170 & 0.021 & 4.04 & 0.403 & \\
\hline D9 Not only for privileged & 0.055 & 0.159 & 0.709 & 0.039 & 0.022 & 0.043 & 3.88 & 0.446 & \\
\hline D12 Make life easier & 0.064 & 0.168 & 0.566 & 0.021 & 0.245 & 0.198 & 3.83 & 0.465 & \\
\hline $\begin{array}{l}\text { B4 Like to talk about information } \\
\text { technology }\end{array}$ & 0.124 & 0.067 & 0.067 & 0.760 & 0.077 & 0.069 & 4.17 & 0.541 & \multirow{4}{*}{0.701} \\
\hline B5 Enjoyable & 0.076 & 0.107 & 0.106 & 0.670 & 0.033 & 0.205 & 4.02 & 0.497 & \\
\hline B6 Like using computers & 0.024 & 0.254 & 0.043 & 0.614 & 0.034 & 0.290 & 4.25 & 0.474 & \\
\hline B2 Feel comfortable & 0.156 & 0.130 & 0.014 & 0.700 & .079 & 0.099 & 4.12 & 0.443 & \\
\hline Eigenvaues & 6.37 & 2.19 & 1.57 & 1.39 & 1.21 & 1.05 & \multirow{3}{*}{\multicolumn{3}{|c|}{ Overall Cronbach alpha $=0.870$}} \\
\hline$\%$ of variance & 30.48 & 8.87 & 6.28 & 5.58 & 4.80 & 4.21 & & & \\
\hline Cum $\%$ of variance & 30.48 & 39.35 & 45.63 & 51.21 & 56.01 & 60.22 & & & \\
\hline
\end{tabular}

F = Factor; F1 = ICT competence; F2 = Learning enhancement; F3 = Work enhancement; F4 = Work enjoyment;

F5 = Positive attitude towards a learning tool; F6 = Teaching enhancement.

\subsubsection{ICT Competence}

Factor 1 was labelled 'ICT Competence', which relates closely to 'ease of use' from the Technology acceptance model (TAM). This factor explained $30.48 \%$ of the variance and comprised four variables. This factor relates to teachers' confidence in ICT usage. An important determinant of teachers' levels of engagement in ICT is their level of confidence in using these technologies in the classroom or in communicating with learners (Peeraer \& Van Petegem, 2011). This factor accounts for the most of the variance, suggesting that teachers place greater prominence on this factor.

Confidence emerges from competence to handle a wide range of varying computer applications for various purposes (Van Braak, Tondeur \& Valcke 2004). According to Berner (2003), Na (1993) and Kutluca and Ekici (2010), teachers' computer competence is a major predictor of integrating ICT in teaching. Evidence suggests that most teachers who reported negative or neutral attitudes towards integration of ICT into teaching and learning processes lacked knowledge and skills that would allow them to make 'informed decisions' resulting primarily from a lack of confidence in using ICT $(\mathrm{Ko0}, 2008)$. This adds to the growing concern that those teachers who have little or no confidence in using computers in their work will try to avoid them altogether, through avoidance behaviours or by making excuses (SteflMabry, Radlick \& Doane, 2010; Liu, 2011). While a lack of personal access or technical problems may lead to a lack of ICT adoption, teacher confidence or a lack thereof may in itself magnify effects of ICT usage among teachers (Jones, 2004).

\subsubsection{Learning Enhancement}

Factor 2 was labelled 'Learning Enhancement', which relates closely to 'perceived usefulness' from TAM, and explained $8.87 \%$ of the variance and comprised five variables. According to Jones (2004) teachers feel reluctant to use computers if they lack confidence. Fear of failure and lack of ICT knowledge have been cited as some of the reasons for teachers' lack of confidence in adopting and integrating ICT into their teaching (Selwyn, 2007).

The use of ICT enhances learning by making teachers less dependent on teaching as a vehicle for the mere transmission of knowledge, instead making learners more responsible for their own learning (self-paced learning). This factor depicts the new kind of learning paradigm which requires learners to be more responsible for their own learning, in line with the recent promotion of a learner-centred pedagogical approach (; Duffy \& Cunningham, 1996; Hirumi, 2002), and lifelong learning in education and society due to the advent of ICT and e-learning platforms (Garrison \& Anderson, 2003). 
The contemporary debate of technology integration focuses on facilitating student development and learning through a conceptual understanding that instructional processes are only a means to an end, and during this process teachers should facilitate learning with the required ICT competence in order to deliver academic content. This calls for varied teaching-learning approaches, such as project-based learning, which is primarily learner-centred (Inan, Lowther, Ross, \& Strahl, 2010). Yen and Lee (2011) demonstrated that students who engage in classroom group discussions and report-writing using technology performed better in terms of learning achievement than unengaged students. In keeping with the constructivist learning approach, teachers act as coaches or facilitators rather than teachers who merely teach and disseminate learned knowledge. During learning, learners use in-depth questioning to acquire information, and should interact with classmates in order to find solutions of contextualised problems.

When students work in small groups they can contribute to a common understanding and develop their verbal and social skills, are familiar with sharing personal opinions, and know where to find information and how to identify data through the use ICT (Nussbaum et al., 2009).

\subsubsection{Work Enhancement}

Factor 3 was labelled 'Work Enhancement', which relates closely to 'performance expectancy' from the UTAUT model. This factor explained $6.28 \%$ of the variance and comprised five variables. One key area of teachers' attitudes towards ICT is their understanding of how it will benefit their work and their students' learning (Jones, 2004). Cox (2008) expresses the need to measure, among other factors, teachers' beliefs and understanding of the role of ICT within the subject being taught.

Kirkup and Kirkwood (2005) distinguish innovators, who are enthusiastic for the technology as valuable itself, and later adopters who are less interested in the technology and need evidence that it will improve their lives or work. Not only does ICT enhance the development of learners, it also enhances development of teaching instruction by teachers. According to research conducted in South African secondary schools by Bialobrzeska and Cohen (2005), the use of ICT in schools assisted teachers to administer and manage their work more efficiently; moreover, teachers were able to work faster and communicate more efficiently with other teachers and colleagues in their respective school communities.

\subsubsection{Work Enjoyment}

Factor four was labelled 'Work Enjoyment', which relates closely to 'effort expectancy' from the UTAUT model. This factor explained $5.58 \%$ of the variance and comprised five variables. Enjoyment is defined as the degree to which the activity of using technology is perceived to be enjoyable in its own right, apart from any performance consequences that may be anticipated (Bagozzi et al., 1992). Research has found that enjoyment plays an important role in user acceptance of echnology (Venkatesh \& Speier, 1999; Yang \& Chen, 2007).

\subsubsection{Positive Attitude Towards a Learning Tool}

Factor five was labelled 'Positive Attitude Towards a Learning Tool', which relates closely to 'attitude towards behaviour' from the TRA model. This factor explained $4.80 \%$ of the variance and comprised four variables. Ether (in Jones, 2004:12) states that "there is little point in providing large quantities of equipment if teachers do not have the attitudes necessary to change their classroom practices".

Based on shifts in the learning paradigm, technology can help teachers develop constructivist-based teaching activities. Constructivist use of technology during instruction can facilitate high-order thinking on the part of students (Baylor \& Ritchie, 2002). To successfully initiate and implement educational technology in a classroom largely depends upon teachers' positive attitude towards ICT as a learning tool. When teachers believe that ICT is neither fulfilling their needs nor their students' needs, it is likely that they will not integrate the technology into their teaching and learning.

Among the factors that influence successful integration of ICT into teaching are teachers' attitudes and beliefs towards technology (Hew \& Brush, 2007; Keengwe \& Onchwari, 2008). If teachers' attitudes are positive toward the use of educational technology, then they can easily provide useful insights about their experiences on adoption and integration of ICT into teaching and learning processes. Previous research has affirmed that teachers' computer experience relates positively to their attitudes towards (Buabeng-Andoh, 2012). The more experience teachers have with computers, the more likely that they will show positive attitudes towards computers (Rozell \& Gardner, 1999). Positive computer attitudes are expected to foster computer integration in the classroom (Van Braak et al., 2004). According to Woodrow (1992), for successful transformation in educational practice users need to develop positive attitudes toward the 
innovation.

\subsubsection{Teaching Enhancement}

Factor six was labelled 'Teaching Enhancement', which relates closely to 'perceived usefulness' from TAM. This factor explained $4.21 \%$ of the variance and comprised three variables. Tinio (2003) affirms that the introduction of ICT in education is a powerful tool for educational change and reform, which becomes a catalyst to promote and drive the acquisition of knowledge of learners whereby learners become empowered for lifelong learning and promote new ways of learning. e-Learning Africa Report (2012) revealed, inter alia, the following benefits that accrue to learners and teachers: motivation to learn, learning becomes fun, promotion of independent learning with proper guidance from teachers, creation of new knowledge by learners, and access to quality learning material.

\section{Limitations}

One of the limitations of the study is the representation of the teachers, who were chosen from public schools in a certain geographical part of the province. Therefore these findings cannot be generalised to the entire teacher population in one or more provinces or the country.

ICT can also improve the efficiency of school administration functions (Mueller, Wood, Willoughby, Ross \& Specht, 2008); however, this perspective was not studied, as the main aim was approached from a pedagogic viewpoint. Future research can include such a perspective in order to establish a comprehensive appreciation of the use of ICT in schools. Further research can be conducted to identify a more comprehensive model to explain teachers' perceived usefulness and adoption of ICT in schools.

\section{Conclusion}

The adoption of technology is similar to the adoption of any other educational innovations - however, it is even more time-consuming, labour-intensive and expensive. The risks of not using technology are too great when the rapid pace at which knowledge is expanding is considered together with the need to communicate and compete globally in an information technology community of practice. Research shows that adopting and using ICT in schools leads to significant expansion of education and pedagogical outcomes which are beneficial to both teachers and students.

When used appropriately, ICT can help to strengthen the importance of education to an increasingly networked society, raising the quality of education by making learning and teaching an active process connected to real life (Govender, 2013). However, studies suggest that benefits of adopting and using ICT in schools are not always automatic, as the effective implementation of ICT in schools is a multifaceted, complex process that does not just involve providing the technology to schools but also involves teachers' competencies, schools' readiness, long-term financing, curriculum restructuring and the Government's willingness to invest in the teaching and learning infrastructure (Govender, 2006).

In practice, the usual teaching and curricula approaches remain basically unchanged in many schools, often being skewed more towards the traditional ways of teaching, which makes it difficult to move towards a constructivist approach to teaching and learning (Yilmaz, 2011). Across Africa many countries have started investing considerable amounts of money and designing new policies aimed at making teachers adopt ICT in schools. Perhaps it is time for the Government's education policy makers to earnestly invest in ICT in schools.

However, there are many challenges - some of which could be attributed to teachers' skills in using ICTs (Govender, 2006). For ICT to be effectively implemented in schools, teachers should be prepared to face challenges that accompany its implementation. The use of ICT supports constructivist pedagogy, wherein students use technology to explore and reach an understanding of concepts and content. This approach [constructivism] promotes higher-order thinking and better problem-solving strategies. However, in order to take effective advantage of the benefits of the integration of ICT within the curriculum and within the different subject areas, there has to be a shift from the traditional methods of teaching. New, innovative forms of teaching have to be embraced in order to effectively maximise integration of the technology (Abuhmaih, 2011).

\section{References}

Abuhmaih, A. (2011). ICT training courses for teacher professional development in Jordan. Turkish Online Journal of Educational Technology, 10(4), 195-210. Retrieved 
November 14, 2011, from http://www.tojet.net/articles/10420.pdf

Ajzen, I., \& Fishbein, M. (1980). Understanding attitudes and predicting social behavior, Englewood Cliffs, New Jersey: Prentice-Hall.

Albirini, A. (2006).Teachers' attitudes toward information and communication technologies: the case of Syrian EFL teachers. Computers \& Education, 47, 373-398.

Bagozzi, R. P., Davis, F. D., \& Warshaw, P. R. (1992). Development and test of a theory of technological learning and usage. Human Relations, 45(7), 660-686.

Baylor, A., \& Ritchie, D. (2002). What factors facilitate teacher skill, teacher morale, and perceived student learning in technology-using classrooms? Computers \& Education, 39(1), 395-414.

Berner, J. E. (2003). A study of factors that may influence faculty in selected schools of education in the Commonwealth of Virginia to adopt computers in the classroom, Doctoral thesis, George Mason University, ProQuest Digital Dissertations.

Bialobrzeska, M., \& Cohen, S. (2005). Managing ICTs in South African schools: A guide for school principals. [Online] South African Institute for Distance Education (SAIDE). Available: http://www.unterricht.educa.ch/de/literaturliste [Accessed 12 May 2014].

Buabeng-Andoh, C. (2012). Factors influencing teachers' adoption and integration of information and communication technology into teaching: A review of the literature. International Journal of Education and Development using Information and Communication Technology, 8(1), 136-155.

Bullock, D. (2004). Moving from theory to practice: an examination of the factors that pre-service teachers encounter as they attempt to gain experience teaching with technology during field placement experiences. Journal of Technology and Teacher Education, 12(2), 211-237.

Carle, C.A., Jaffe, D., \& Miller, D. (2009). Engaging college science students and changing academic achievement with technology: A quasi-experimental preliminary investigation. Computers \& Education 52(2), 376-380.

Celik, V., \& Yesilyurt, E. (2013). Attitudes to technology, perceived computer self-efficacy and computer anxiety aspredictors of computer supported education, Computers\& Education, 60(1), 148-158.

Chai, C. S., Hong, H.-Y., \& Teo, T. T. (2009). Singaporean and Taiwanese pre-service teacher beliefs and their attitude towards ICT: a comparative study. Asia-Pacific Education Researcher, 18(1), 117-128.

Chan, K.-W., \& Elliot, R. G. (2004). Relational analysis of personal epistemology and conceptions about teaching and learning. Teaching and Teacher Education, 20, 817-831.

Cox, M. J. (2008). Researching IT in education. In J. Voogt, \& G. Knezek (Eds.), International handbook of information technology in primary and secondary education (vol. 20, pp. 965-981),Springer.

Cutrim, E. (2008). Potential pedagogical benefits and drawbacks of multimedia use in the English language classroom equipped with interactive whiteboard technology. Computers \& Education, 51(4), 1553-1568.

Davis, F. D. (1989). Perceived usefulness, perceived ease of use, and user acceptance of Information Technology. MIS Quarterly, 13(3), 319-339.

Davis, F. D., Bagozzi, R. P., \& Warshaw, P. R. (1989). User acceptance of computer technology: A comparison of two theoretical models. Management Science, 35(8), 982-1002.

Davis, F. D., Bagozzi, R. P., \&Warshaw, P. R. (1992). Extrinsic and intrinsic motivation to use computers in the workplace. Journal of Applied Social Psychology, 22(14), 1111- 1132.

De Vaus, D. (2002). Analysing social science data. London: Sage Publications.

Duffy, T. M., \& Cunningham, D. J. (1996). Constructivism: Implication for the design and delivery of instruction. In D. H. Jonassen (Ed.), Handbook of research for educational communications and technology (pp. 170-197). NY: Simon \& Schuster Macmillan.

Dwyer, D.C., Ringstaff, C., \& Sandholtz, J. (1991). Changes in teachers' beliefs and practices in technology-rich classrooms. Educational Leadership, 48(8), 45-52.

Department of Education. (2003). Draft White Paper on e-Education: Transforming learning and teaching through ICT. Pretoria: Government Printer.

E-learning Africa Report. (2012). The e-learning Africa Report 2012. [Online] Available: http://www.elearning-africa.com/report2012 [Accessed 6 June 2014].

Ertmer, P. A. (2005). Teacher pedagogical beliefs: the final frontier in our quest for technology integration? Educational Technology Research and Development, 53(4), 25-39.

Friedman, H. H. \& Friedman, L. W. (2011). Crises in Education: Online Learning as a Solution. Creative Education, 2(3), $156-163$.

Garrison, D. R., \& Anderson, T. (2003). E-Learning in the 21st century. London: Routledge Falmer.

Govender, D. W. (2006). Information and communication Technology Integration in Teaching and Learning: A Critical Analysis. PhD thesis, University of KwaZulu-Natal, South Africa.

Govender, D. W. (2013). Using perceptual control theory to analyse technology integration in teaching. Journal for Transdisciplinary Research in Southern Africa, 9(1), 171-181.

Govender, D. W. (2010). The attitudes of students towards the use of a learning management system in a face to face learning mode of instruction. African Education Review, 2, 244-262.

Govender, D. W. (2012). A model to predict educators' attitudes towards technology and thus technology adoption. African Education Review, 9(3), 548-568.

Govender, D. W., \& Govender, I. (2009). The relationship between Information and Communications Technology (ICT) integration and teacher's self-efficacy beliefs about ICT. Education as Change, 13(1), 153-165.

Govender, D. W., \& Govender, I. (2013). Technology adoption: A different perspective in a developing country. Paper presented at the 
5th World Conference on Educational Sciences, 5-8 February 2013, Sapienza University of Rome, Italy.

Govender, D. W., \& Maistry, S. (2012). An investigation into teachers' propensity for technology adoption. Journal of Social Sciences, 39 (2), 193-202.

Gulbahar, Y. (2007). Technology planning: A roadmap to successful technology integration in schools. Computers \& Education, 49(4), 943-956.

Hew, K. F., \& Brush, T. (2007). Integrating technology into K-12 teaching and learning: current knowledge gaps and recommendations for future research. Educational TechnologyResearch and Development, 55, 223-253.

Higgins, S., \& Moseley, D. (2001). Teachers, thinking about information and communications technology and learning: beliefs and outcomes. Teacher Development, 5(2), 191-210.

Hirumi, A. (2002). Student-centered, technology-rich learning environments (SCenTRLE): Operationalizing Constructivist approaches to teaching and learning. Journal of Technology and Teacher Education, 10(4), 497-537.

Honey, M., \& Moeller, B. (1990). Teachers' beliefs and technology integration: Different understandings. Technical report No. 6. Washington, D.C: Office of Educational Research and Improvement.

Hu, P. J., Chau, P. Y. K., Sheng, O. R. L., \& Tam, K.Y. (1999). Examining the technology acceptance model using physician acceptance of telemedicine technology. Journal of Management Information Systems, 16(2), 91-112.

Inan, F. A., \& Lowther, D. L. (2010). Laptops in the K-12 classrooms: exploring factors impacting instructional use. Computers \& Education, 55(3), 937-944.

Inan, F. A., Lowther, D. L., Ross, S. M., \& Strahl, D. (2010). Pattern of classroom activities during students' use of computers: relations between instructional strategies and computer applications. Teaching and Teacher Education, 26(3), 540-546.

Jaber, W. (1997). A survey of factors which influence teachers' use of computer-based technology, Masters dissertation, Virginia Polytechnic Institute and State University, ProQuest Digital Dissertations.

Jones, A. (2004). A review of the research literature on barriers to the uptake of ICT by teachers. British Educational Communications and Technology Agency.

Keengwe, J., \& Onchwari, G. (2008). Computer technology integration and student learning: Barriers and promise. Journal of Science Education and Technology, 17, 560-565.

Kersaint, G., Horton, B., Stohl, H., \& Garofalo, J. (2003). Technology beliefs and practices of mathematics education faculty. Journal of Technology and Teacher Education, 11(4), 549-577.

Kim, M.C., \& Hannifin, M. J. (2011). Scaffolding problem solving in technology-enhanced learning environments (TELES): Bridging research and theory with practice. Computers \& Education, 56 (2), 403-417.

Kirkup, G., \& Kirkwood, A. (2005). Information and communications technologies (ICT) in higher education teaching: a tale of gradualism rather than revolution. Learning, Media, \& Technology, 30(2), 185-199.

Koo, A. C. (2008). Factors affecting teachers' perceived readiness for online collaborative learning: A case study in Malaysia. Educational Technology \& Society, 11(1), 266-278.

Kutluca, T., \& Ekici, G. (2010). Examining teacher candidates' attitudes and self-efficacy perceptions towards computer assisted education. Journal of Education, 38, 177-188.

Leedy, P. D., \& Ormrod, J. E. (2005). Practical Research-Planning and Design. (8th ed.). New Jersey: Pearson Education.

Liu, S. H. (2011). Factors related to pedagogical beliefs of teachers and technology integration. Computers \& Education, 56, 1012-1022.

Meirink, J. A., Meijer, P. C., Verloop, N., \& Bergen, T. C. M. (2009). Understanding teacher learning in secondary education: the relations of teacher activities to changed beliefs about teaching and learning. Teaching and Teacher Education, 25(1), 89-100.

Mueller, J., Wood, E., Willoughby, T., Ross, C., \& Specht, J. (2008). Identifying discriminating variables between teachers who fully integrate computers and teachers with limited integration. Computers \& Education, 51(4), 1523-1537.

$\mathrm{Na}$, S.I. (1993). Variables associated with attitudes of teachers toward computers in Korean vocational agriculture high schools, Doctoral thesis, Ohio State University, ProQuest Digital Dissertations.

Neyland, E. (2011). Integrating online learning in NSW secondary schools: Three schools' perspectives on ICT adoption. Australia Journal of Educational Technology, 27(1), 152-173.

Nunnally, J., \& Bernstein, I. (1994). Psychometric theory. New York, McGraw-Hill.

Nussbaum, M., Alvarez, C., McFarlane, A., Gomez, F., Claro, S., \& Radovic, D. (2009). Technology as small group face-to-face Collaborative Scaffolding. Computers \& Education, 52(1),147-153.

Peeraer, J. \& Van Petegem, P. (2011). ICT in teacher education in an emerging developing country: Vietnam's baseline situation at the start of 'The Year of ICT'. Computers \& Education, 56, 974-982.

Pelgrum, W. J. (2001). Obstacles to the integration of ICT in education: results from a worldwide educational assessment. Computers \& Education, 37, 163-178.

Rozell, E. J., \& Gardner, W. L. (1999). Computer-related success and failure: a longitudinal field study of the factors influencing computer-related performance. Computers in Human Behavior, 15(1), 1-10.

Samuelowicz, K., \& Bain, J. D. (2001). Revisiting academics' beliefs about teaching and learning. Higher Education, 41, $299-325$.

Schuh, K. L. (2004). Learner-centered principles in teacher-centered practices? Teaching and Teacher Education, 20(8), 833-846.

Selwyn, N. (2007). The use of computer technology in university teaching and learning: a critical perspective. Journal of Computer Assisted Learning, 23(2), 83-94.

Stefl-Mabry, J., Radlick, M., \& Doane, W. (2010). Can you hear me now? Student voice: High school \& middle school students' perceptions of teachers, ICT and learning International Journal of Education and Development using Information and 
Communication Technology, 6(4), 64-82.

Tabachnick, B. G., \& Fidell, L. S. (2001). Using Multivariate Statistics. (4th ed.). Boston: Allyn and Bacon.

Taylor, S., \& Todd, P. A. (1995). Assessing IT Usage: The Role of Prior Experience. MIS Quarterly, 19(2), 561-570.

Tinio, V. (2003). ICT in Education.[Online] ICT for Development. United Nations Development Programme, Bureau for Development Policy. Available: http://www.adip.net/publications/iespprimers/eprimer-edu.pdf [Accessed 6 June 2014].

Van Braak, J., Tondeur, J., \& Valcke, M. (2004). Explaining different types of computer use among primary school teachers. European Journal of Psychology of Education, 19, 407-422.

Vannatta, R. \& O'Bannon, B. (2002). Beginning to put pieces together: Technology infusion model for teacher education. Journal of Computing in Teacher Education, 18(4), 112-123.

Venkatesh, V. \& Davis, F. D. (2000). A theoretical extension of the technology acceptance model: Four longitudinal field studies. Management Science, 46(2), 186-204.

Venkatesh, V., Morris, M. G., Davis, G. B., \& Davis, F. D. (2003). User acceptance of information technology: Toward a unified view. MIS Quarterly, 27(3), 425-478.

Venkatesh, V., \& Speier, C. (1999). Computer technology training in the workplace: A longitudinal investigation of the effect of the mood. Organizational Behavior and Human Decision Processes, 79(1), 1-28.

Voogt, J. (2010). Teacher factors associated with innovative curriculum goals and pedagogical practices: differences between extensive and non-extensive ICT-using science teachers. Journal of Computer Assisted Learning, 26(6), 449-586.

Ward, L., \& Parr, J. (2010). Revisiting and Reframing use: implications for the Integration of ICT. Computers \& Education, 54(1), 113122.

Wilson, B., Sherry, L., Dobrovolny, J., Batty, M., \& Ryder M. (2002). Handbook on Information Technologies for Education and Training. International Handbooks on Information Systems, pp 293-307.

Woodrow, J. E. (1992). The influence of programming training on the computer literacy and attitudes of pre-service teachers. Journal of Research on Computing in Education, 25(2), 200-219.

Yang, S. H., \& Chen, Yi-Ju (2007). Technology-enhanced language learning: a case study. Computers in Human Behavior, 23, 860-879.

Yen, J.-C., \& Lee, C.-Y. (2011). Exploring problem solving patterns and their impact on learning achievement in a blended learning environment. Computers \& Education, 56(1), 138-145.

Yilmaz, N. P. (2011). Evaluation of the Technology Integration Process in the Turkish Education System. Contemporary Educational Technology, 2 (1) 37-54. 